\title{
Long-term assessment of children exposed in utero to carbimazole
}

\author{
ANNE M. McCARROLL, MAY HUTCHINSON, R. McAULEY, and D. A. D. MONTGOMERY \\ From the Metabolic Unit, Royal Victoria Hospital, and Department of Child Guidance, Royal Belfast Hospital \\ for Sick Children, Belfast
}

\begin{abstract}
McCarroll, A. M., Hutchinson, M., McAuley, R., and Montgomery, D. A. D. (1976). Archives of Disease in Childhood, 51, 532. Long-term assessment of children exposed in utero to carbimazole. Twenty-five children aged 3 to 13 years who had been exposed in utero to carbimazole were assessed physically and psychologically to evaluate the long-term effects of the drug on growth and development. 2 children had congenital malformations but all had normal pituitary-thyroid function and appeared to have grown and developed normally.
\end{abstract}

Since the introduction of thiocarbamide derivatives for the treatment of thyrotoxicosis in 1943 there have been many reports alleging serious effects on human fetal thyroids when these drugs have been administered during pregnancy (Davis and Forbes, 1945; Hepner, 1952; Man, Shaver, and Cooke, 1958). On the other hand, the delivery of normal infants after the controlled use of these drugs in pregnant hyperthyroid women has also been frequently described (Astwood, 1951; Piper and Rosen, 1954). All of these observations have been made in the neonatal period, but the delivery of an apparently normal live-born infant at term does not necessarily indicate that the product of pregnancy is completely satisfactory. It is impossible either to recognize with certainty all congenital malformations at birth, or to evaluate the developmental capabilities of the infant at this time (Lowrey et al., 1958; Warkany and Kalter, 1961; Lock, Gatling, and Wells, 1961). Only long-term follow-up can answer the question as to whether this therapy in the pregnant patient with thyrotoxicosis has any harmful effects on the subsequent development of the child. Two groups of workers (Greenman et al., 1962; Burrow et al., 1968) have already carried out such an assessment 1 to 10 years after delivery in children born to mothers treated with propylthiouracil during pregnancy. We report here the long-term evaluation of the offspring of thyrotoxic women treated during pregnancy with carbimazole (Neo-Mercazole), a chemically related antithyroid compound.

\footnotetext{
Received 3 October 1975.
}

\section{Patients and methods}

Twenty-five children born born to carbimazoletreated thyrotoxic women in the years 1960 to 1971 inclusive were studied. In all cases a complete history was obtained and full physical examination carried out. Height and weight were measured and compared with corresponding estimates for Northern Ireland boys and girls obtained from routine medical inspections made in 1972. Bone age was assessed (Tanner, Whitehouse, and Goldstein, 1972).

Thyroid-function studies. Blood samples were taken from 24 of the children for determination of serum protein-bound iodine (PBI), free thyroxine index (FTI), tri-iodothyronine (T3), and thyroid stimulating hormone (TSH). The mother of Case 24 (Table I) refused permission for venepuncture. PBI was measured with an autoanalyser, normal range $3 \cdot 5-8 \cdot 0 \mu \mathrm{g} / 100 \mathrm{ml}$. Serum thyroxine was estimated by competitive protein binding using Thyopac-4 (Amersham) and residual thyroid-hormone-binding capacity of serum measured by Thyopac-3 (Amersham), and the FTI was calculated (Bell et al., 1974). The normal range for FTI was taken as 4-11. Serum T3 and TSH were measured by specific radioimmunoassay. The upper and lower limits of normality were derived from measurements made on the sera of 30 healthy matched control children who attended hospital for minor surgical procedures. For $T 3$ the normal range lay between 100 and 260 $\mathrm{ng} / 100 \mathrm{ml}$ (mean $196 \cdot 2 \pm 39 \cdot 7 \mathrm{SD}$ ) and for TSH 0.5 to $8 \cdot 0 \mu \mathrm{U} / \mathrm{ml}$ (mean $3 \cdot 6 \pm 4 \cdot 0 \mathrm{SD}$ ).

Psychometric and behavioural studies. Psychological testing of the children was designed to evaluate the following four factors: (1) physical health, (2) hospitalization, (3) behavioural health, and (4) intelligence quotient (IQ). The first three were assessed 
using the Buckinghamshire Screening Questionnaire (Shepherd, Oppenheim, and Mitchell, 1971) completed by the parent in the presence of a psychiatric social worker. This instrument counts as significant only behavioural problems which occur in under $10 \%$ of a standardized group of children aged between 5 and 15 years. Children scoring four or more of such problems are judged deviant. The Buckinghamshire Screening Questionnaire was also completed in the same manner for 25 control children. This group consisted of children born within the same week and in the same hospital as the index children and were matched for sex, social class, and area of origin. IQ was assessed using standard tests suited to the subject's age (Wechsler, 1949, 1967; Stutsman, 1948). Case 24 who was unable to co-operate satisfactorily was excluded from IQ assessment. The mental health of all the mothers was assessed using the Middlesex Hospital Questionnaire (MHQ) (Crown and Crisp, 1966).

All the mothers had been diagnosed as thyrotoxic before the onset of pregnancy both by standard clinical criteria and by measurements of PBI and T3 red blood cell uptake, and evaluation of thyroid status throughout pregnancy was continued by similar means. An average daily dosage of $30 \mathrm{mg}$ carbimazole, administered in divided doses, was received in every case during the first two trimesters of pregnancy. This was reduced to an average of $10-20 \mathrm{mg} / \mathrm{d}$ in the last trimester. All the mothers received $0 \cdot 1-0.2 \mathrm{mg}$ thyroxine daily throughout pregnancy. The infants had been assessed clinically at birth and at 2-5 days of age.

\section{Results}

Table I lists the physical characteristics and thyroid function tests of the 25 children studied.

Clinical examination. 22 of the 25 showed no obvious abnormality on clinical examination. One child (Case 9) had a small goitre but was clinically and biochemically euthyroid. Case 10 had partial adactyly of the right foot. A third (Case 24) had bilateral congenital cataracts with considerable impairment of visual acuity.

Height and weight. No child was outside the normal range for height or weight, i.e. the 50th centile \pm 2 SD.

Bone maturation. All skeletal ages shown in Table I are within the normal range.

Thyroid function. It will be seen from Table I that while some individual results fell into either the hypo- or hyperthyroid range (FTI in Cases 2 and 10; PBI in Case 23; T3 in Case 8), no complete test battery was abnormal in any single child.

Psychological data. The results of psychological testing were as follows.

TABLE I

Physical characteristics and thyroid function tests

\begin{tabular}{|c|c|c|c|c|c|c|c|c|c|}
\hline Case no. & Sex & $\begin{array}{c}\text { Age } \\
\text { (years) }\end{array}$ & $\begin{array}{c}\text { Bone age } \\
\text { (years) }\end{array}$ & $\begin{array}{c}\text { Height } \\
(\mathrm{cm})\end{array}$ & $\begin{array}{l}\text { Weight } \\
\text { (kg) }\end{array}$ & FTI & $\begin{array}{c}\text { PBI } \\
(\mu \mathrm{g} / 100 \mathrm{ml})\end{array}$ & $\begin{array}{c}\mathrm{T} 3 \\
(\mathrm{ng} / 100 \mathrm{ml})\end{array}$ & $\begin{array}{c}\text { TSH } \\
(\mu \mathrm{U} / \mathrm{ml})\end{array}$ \\
\hline $\begin{array}{r}1 \\
2 \\
3 \\
4 \\
5 \\
6 \\
7 \\
8 \\
9 \\
10 \\
11 \\
12 \\
13 \\
14 \\
15 \\
16 \\
17 \\
18 \\
19 \\
20 \\
21 \\
22 \\
23 \\
24 \\
25\end{array}$ & $\begin{array}{l}M \\
M \\
M \\
M \\
M \\
M \\
M \\
M \\
F \\
F \\
F \\
F \\
F \\
F \\
F \\
F \\
F \\
F \\
F \\
F \\
F \\
F \\
F \\
F \\
F\end{array}$ & $\begin{array}{r}13 \cdot 3 \\
13 \cdot 3 \\
9 \cdot 2 \\
7 \cdot 9 \\
6 \cdot 0 \\
4 \cdot 4 \\
4 \cdot 0 \\
3 \cdot 6 \\
12 \cdot 7 \\
13 \cdot 2 \\
13 \cdot 1 \\
12 \cdot 7 \\
12 \cdot 4 \\
10 \cdot 1 \\
9 \cdot 9 \\
9 \cdot 6 \\
9 \cdot 5 \\
7 \cdot 8 \\
7 \cdot 4 \\
5 \cdot 8 \\
5 \cdot 9 \\
5 \cdot 5 \\
5 \cdot 6 \\
3 \cdot 8 \\
3 \cdot 3\end{array}$ & $\begin{array}{r}13 \cdot 2 \\
13 \cdot 6 \\
9 \cdot 3 \\
9 \cdot 3 \\
6 \cdot 0 \\
4 \cdot 0 \\
3 \cdot 6 \\
4 \cdot 8 \\
13 \cdot 9 \\
15 \cdot 2 \\
15 \cdot 0 \\
13 \cdot 7 \\
14 \cdot 4 \\
11 \cdot 2 \\
10 \cdot 9 \\
10 \cdot 8 \\
10 \cdot 4 \\
5 \cdot 9 \\
4 \cdot 6 \\
6 \cdot 0 \\
7 \cdot 8 \\
6 \cdot 4 \\
7 \cdot 2 \\
4 \cdot 0 \\
2 \cdot 6\end{array}$ & $\begin{array}{r}147 \cdot 8 \\
166 \cdot 5 \\
132 \cdot 5 \\
117 \cdot 0 \\
100 \cdot 6 \\
104 \cdot 3 \\
96 \cdot 4 \\
99 \cdot 2 \\
150 \cdot 9 \\
153 \cdot 7 \\
149 \cdot 2 \\
147 \cdot 3 \\
156 \cdot 4 \\
133 \cdot 4 \\
131 \cdot 2 \\
137 \cdot 5 \\
141 \cdot 2 \\
114 \cdot 5 \\
119 \cdot 6 \\
114 \cdot 1 \\
113 \cdot 2 \\
113 \cdot 2 \\
104 \cdot 1 \\
100 \cdot 1 \\
99 \cdot 3\end{array}$ & $\begin{array}{l}36 \cdot 74 \\
53 \cdot 00 \\
31 \cdot 75 \\
21 \cdot 31 \\
19 \cdot 50 \\
14 \cdot 51 \\
14 \cdot 06 \\
17 \cdot 69 \\
40 \cdot 37 \\
44 \cdot 45 \\
53 \cdot 97 \\
36 \cdot 74 \\
49 \cdot 4 \\
33 \cdot 11 \\
27 \cdot 21 \\
29 \cdot 48 \\
40 \cdot 37 \\
18 \cdot 59 \\
23 \cdot 58 \\
19 \cdot 5 \\
21 \cdot 32 \\
19 \cdot 95 \\
19 \cdot 95 \\
19 \cdot 95 \\
16 \cdot 32\end{array}$ & $\begin{array}{r}9 \cdot 0 \\
\star 2 \cdot 9 \\
8 \cdot 7 \\
9 \cdot 1 \\
5 \cdot 2 \\
5 \cdot 4 \\
7 \cdot 2 \\
7 \cdot 2 \\
7 \cdot 3 \\
\star 3 \cdot 5 \\
6 \cdot 2 \\
10 \cdot 0 \\
4 \cdot 5 \\
5 \cdot 9 \\
6 \cdot 7 \\
7 \cdot 6 \\
4 \cdot 4 \\
4 \cdot 9 \\
7 \cdot 8 \\
5 \cdot 2 \\
6 \cdot 8 \\
4 \cdot 8 \\
7 \cdot 5 \\
-8 \\
8 \cdot 1\end{array}$ & $\begin{array}{r}5 \cdot 6 \\
4 \cdot 5 \\
5 \cdot 9 \\
7 \cdot 9 \\
7 \cdot 1 \\
6 \cdot 4 \\
6 \cdot 2 \\
- \\
3 \cdot 9 \\
5 \cdot 3 \\
6 \cdot 6 \\
7 \cdot 2 \\
6 \cdot 7 \\
6 \cdot 6 \\
7 \cdot 7 \\
5 \cdot 8 \\
4 \cdot 8 \\
7 \cdot 0 \\
8 \cdot 0 \\
5 \cdot 9 \\
6 \cdot 6 \\
6 \cdot 5 \\
\star 13 \cdot 0 \\
- \\
8 \cdot 2\end{array}$ & $\begin{array}{c}175 \\
180 \\
175 \\
145 \\
160 \\
245 \\
195 \\
\star 290 \\
225 \\
175 \\
200 \\
255 \\
230 \\
180 \\
150 \\
165 \\
185 \\
225 \\
190 \\
175 \\
145 \\
225 \\
255 \\
- \\
240\end{array}$ & $\begin{array}{c}2 \\
2 \\
6.0 \\
5.5 \\
3.5 \\
3.5 \\
4.5 \\
<0.5 \\
2 \\
<0.5 \\
<0.5 \\
2.0 \\
2.5 \\
3.0 \\
1.0 \\
2.0 \\
2.0 \\
3.5 \\
6.0 \\
1.5 \\
3.5 \\
2.0 \\
<0.5 \\
- \\
2\end{array}$ \\
\hline
\end{tabular}

$\star$ Abnormal result.

FTI, free thyroxine index; PBI, protein-bound iodine,; T3, tri-iodothyronine; TSH, thyroid stimulating hormone. 
Physical health. According to information obtained from the mothers by questionnaire, $84 \%$ of the group had three minor physical problems or less. No child had five or more problems. Only one major health problem was reported, i.e., bilateral cataract in Case 24 . Only one psychosomatic problem was recorded.

Hospitalization. 10 of the 25 subjects had at some time required hospitalization. 8 admissions were for minor routine childhood ailments. One child required treatment as a neonate for Rhesus incompatibility and another had been investigated for failure to thrive, but both appeared to have achieved normal growth and development.

Behavioural health. Table II shows the incidence of behavioural problems in the 20 children of our group aged 5 to 15 years as compared with a control group of Northern Ireland children and the original Buckinghamshire group studied. Children under 5 years were excluded from this part of the study in the absence of reliable norms for comparative purposes. It will be seen that no child in our group, or in the Northern Ireland control group was free of behavioural problems. This contrasts markedly with the $40.7 \%$ of problem-free children in the Buckinghamshire study and was statistically significant $\left(x^{2}=12 \cdot 06, P<0 \cdot 01\right) .8$ of the 20 children in our group (40\%) and 6 of the Northern Ireland control children (30\%) were regarded as deviant with a score of four or more behavioural problems, as compared with only $11.1 \%$ in the Buckinghamshire study. This again was significant $\left(\chi^{2}=14 \cdot 03, P<0 \cdot 001\right)$. Though the numbers are small it appears that the number of children with one, two, or three behavioural problems is similar in the two Northern Ireland groups at around 20 to $30 \%$, but clearly lower in the Buckinghamshire study where $27 \%$ had a problem score of one, while $15 \%$ scored two, and only $8 \%$ scored three. However, there was no statistical difference between scores in these three groups.
Intelligence quotient. Testing in the 24 children studied showed that no single individual had an abnormal IQ. The range was 86-135, with an overall normal mean of $104 \cdot 3 \pm 12 \cdot 3 \mathrm{SD}$ using both the Wechsler and corrected Merrill-Palmer data.

Maternal mental health. The mean scores of the mothers on the Middlesex Hospital Questionnaire were not significantly different from normal. All mothers were recorded as having remained clinically and biochemically euthyroid during pregnancy. All infants were delivered normally at term. Apgar scores were 8 to 10 in all children except in Cases 4,8 , and 15 in whom the score was 6 . None of the children had a goitre, and all were judged clinically euthyroid.

\section{Discussion}

In this series of 25 children ranging in age from 3 to 13 years, no child was outside the normal range for height or weight. All were clinically euthyroid. No adequate explanation can be offered for the individual abnormal thyroid function tests recorded in $\mathbf{4}$ of the children as it was not possible to confirm them by repetition. However, as no complete test battery was abnormal in any single child all were accepted as biochemically euthyroid. None had had a goitre at birth, and all had been judged euthyroid by the paediatricians in the neonatal period. These findings seem to indicate that there had been no drug-induced interference with the development of the fetal pituitary-thyroid axis.

Two of the group had congenital abnormalities. One had bilateral cataracts resulting in marked impairment of visual acuity diagnosed at the age of 4 months, and the other had a minor limb reduction deformity. These 2 children did not differ from the rest of the group or from the controls in any of the other indices examined. The overall incidence of major congenital abnormalities in the Northern Ireland population based on the notifica-

TABLE II

Behavioural problems

\begin{tabular}{|c|c|c|c|}
\hline $\begin{array}{l}\text { No. of } \\
\text { behavioural problems } \\
\text { (deviance score) }\end{array}$ & $\begin{array}{l}\text { Incidence of behavioural } \\
\text { problems in study group } \\
\qquad(\%)(\mathrm{n}=20)\end{array}$ & $\begin{array}{l}\text { Incidence of behavioural } \\
\text { problems in Northern } \\
\text { Ireland control group) } \\
(\%)(n=20)\end{array}$ & $\begin{array}{l}\text { Incidence of behavioural } \\
\text { problems in } \\
\text { Buckinghamshire group } \\
(\%)(n=6160)\end{array}$ \\
\hline $\begin{array}{c}0 \\
1 \\
2 \\
3 \\
4 \text { or more }\end{array}$ & $\begin{array}{l}- \\
10 \\
30 \\
20 \\
40\end{array}$ & $\begin{array}{l}- \\
30 \\
20 \\
20 \\
30\end{array}$ & $\begin{array}{r}40 \cdot 7 \\
26 \cdot 4 \\
14 \cdot 2 \\
7 \cdot 6 \\
11 \cdot 1\end{array}$ \\
\hline
\end{tabular}


tion for the year 1971 is $27 \cdot 3 / 1000$ total births, that of all eye abnormalities $0 \cdot 2 / 1000$, and that of limb reduction deformities $1 \cdot 4 / 1000$. Two malformations in a group of 25 suggests an incidence of abnormality 2 to 3 times greater than in other children in the region, but it is difficult to make valid deductions from such a small number.

There are several possible aetiological explanations for these particular abnormalities. Firstly, they may be genetic in origin. It is well known that congenital cataracts and also certain skeletal limb deficiencies have predominantly genetic causes (Freire-Maia, 1969; Fraser, 1969). Most of these, however, are associated with other multiple defects, while the 2 children in our study are otherwise normal. Further, there was no family history of malformations and both sibships were normal. Secondly, abnormal maternal thyroid hormone production, whether excessive or deficient, may have interfered with the developing fetal lens or limb bud at an early critical stage, i.e. 4-12 weeks' gestation. Neither the exact stage in pregnancy at which the human fetal thyroid is anatomically and functionally mature nor maternal/fetal thyroid hormone exchanges is as yet fully understood (Werner, 1967). It must be assumed that until the fetal pituitary-thyroid system is mature the fetus depends to a varying extent on transplacental passage of thyroid hormones from its mother for normal development. Thyrotoxicosis per se has been variously reported either as having no injurious effects on the development of the offspring (Mussey, Plummer, and Boothby, 1926; Benson et al., 1959) or as being associated with a very high fetal wastage $(45 \%)$ mainly due to the risks inherent in premature delivery, the incidence of which is raised in untreated mothers (GardinerHill, 1929; Mestman, Manning, and Hodgman, 1974). It is generally accepted that pregnancy rarely occurs in the presence of active thyrotoxicosis (Freedberg, Hamolsky, and Freedberg, 1957; Javert, 1940) and the mothers of the affected children in our series had been diagnosed as thyrotoxic and were already on antithyroid therapy before pregnancy began. No relapse of their disease occurred at any stage of gestation. An excess of maternal thyroid hormone would therefore seem unlikely as an explanation for the abnormalities encountered.

In human hypothyroidism many studies have shown a high incidence of physical and mental abnormalities in the offspring, in particular permanent defects of the central nervous system (Man et al., 1958). The mothers of both affected children in this series had remained apparently euthyroid throughout pregnancy on both clinical and labora- tory criteria. However, clinical signs of mild hypothyroidism can easily be obscured by the physiological accompaniments of normal pregnancy, and PBI and T3 red cell uptake measurements are altered by the increase in thyroxine-binding globulin which occurs in pregnancy (Sterling and Brenner, 1966). For this reason these tests have definite limitations as indices of the level of 'free' thyroxine, which is the functionally important fraction both to mother and fetus, and it is therefore impossible to be certain that mild episodes of undetected hypothyroidism did not occur from time to time in these women. Direct hormone assay, and in particular TSH estimation, gives more useful information on this point but has only recently become available.

Finally, it is possible that carbimazole which crosses the placenta very readily (Hamburger, 1972) may itself have been directly toxic to the fetus. There are well recognized difficulties in documenting causal relations between environmental agents and birth defects in humans. With regard to drugs, only the thalidomide cases are well established, but recent reports have suggested an association between congenital limb reduction deformities and exposure to exogenous sex steroids during pregnancy (Janerich, Piper, and Glebatis, 1974; Nora and Nora, 1974; Jaffe et al., 1975). In the context of our case it is of some interest that Janerich et al. (1974) have suggested that this association is not directly causal, but rather the result of some underlying endocrine abnormality in the mother, increasing the risk of her bearing an infant with this type of malformation.

The striking feature of psychological testing in our group of children is the marked increase in the number of behavioural problems which they manifested as compared with the original Buckinghamshire group. In view of the fact that the behavioural findings in our control group were almost identical, the most likely reason for this is simply that the Northern Ireland child population, and particularly those from the Belfast area from which most of the children studied came, may have different behavioural norms due to exposure to conditions of civil unrest from 1969 onwards. This explanation is in keeping with evidence from recent local studies on child behaviour (Fraser, 1973).

The evidence presented in our study suggests that the controlled use of carbimazole for thyrotoxicosis in pregnancy has no injurious effects on the subsequent growth and development of the child. Greenman et al. (1962) and Burrow et al. (1968) came to similar conclusions from their 
investigations of the use of propylthiouracil in pregnancy. The numbers in all of these studies have been small, making it difficult to reach definitive conclusions on such findings as congenital abnormalities and the possible teratogenic effect of antithyroid drugs in susceptible pregnancies. A multicentre prospective study designed to answer such problems seems desirable.

We wish to thank Mr. N. Perl and Dr. W. McC. Nelson for assistance and interest in this work, and Dr. K. MacRae for statistical advice.

\section{REFERENCES}

Astwood, E. B. (1951). The use of antithydroid drugs during pregnancy. Fournal of Clinical Endrocrinology, 11, 1045.

Bell, T. K., Boyle, D. A., Montgomery, D. A. D., and Todd, S. J. (1974). An evaluation of absorbent granule kits for determining serum thyroxine concentration and free thyroxine index in the diagnosis of thyroid function. Fournal of Clinical Pathology, 27,372 .

Benson, R. C., Pickering, D. E., Kontaxis, N. E., and Fisher, D. A. (1959). Thyroid function in pregnancy. Obstetrics and Gynecology, 14, 11.

Burrow, G. N., Bartsocas, C., Klatskin, E. H., and Grunt, J. A. (1968). Children exposed in utero to propylthiouracil; subsequent intellectual and physical development. American Fournal of Diseases of Children, 116, 161.

Crown, S., and Crisp, A. H. (1966). A short clinical diagnostic self-rating scale for psychoneurotic patients. The Middlesex Hospital Questionnaire (MHQ). British fournal of Psychiatry, 112, 917.

Davis, L. G., and Forbes, W. (1945). Thiouracil in pregnancy: effect on foetal thyroid. Lancet, $2,740$.

Fraser, G. R. (1969). Malformation syndromes with eye or ear involvement. Birth Defects Original Articles Series, 5, No. 2. p. 130. The National Foundation, March of Dimes.

Fraser, M. (1973). Children in Conflict. Secker and Warburg, London.

Freedberg, I. M., Hamolsky, M. W., and Freedberg, A. S. (1957). The thyroid gland in pregnancy. New England fournal of Medicine, 256, 551.

Freire-Maia, N. (1969). Congenital skeletal limb deficiencies-a general view. Birth Defects Original Articles Series, 5, No. 3, p. 7. The National Foundation, March of Dimes.

Gardiner-Hill, H. (1929). Pregnancy complicating simple goitre and Graves's Disease. Lancet, 1, 120.

Greenman, G. W., Gabrielson, M. O., Howard-Flanders, J., and Wessel, M. A. (1962). Thyroid dysfunction in pregnancy. Fetal loss and follow-up evaluation of surviving infants. New England fournal of Medicine, 267, 426.

Hamburger, J. I. (1972). Management of the pregnant hyperthyroid. The argument against combined antithyroidthyroid therapy. Obstetrics and Gynecology, 40, 114.
Hepner, W. R., Jr. (1952). Thiourea derivatives and the fetus. A review and report of a case. American fournal of Obstetrics and Gynecology, 63, 869.

Jaffe, P., Liberman, M. M., McFadyen, I., and Valman, H. B. (1975). Incidence of congenital limb-reduction deformities. Lancet, 1, 526.

Janerich, D. T., Piper, J. M., and Glebatis, D. M. (1974). Oral contraceptives and congenital limb-reduction defects. New England fournal of Medicine, 291, 697.

Javert, C. T. (1940). Hyperthyroidism and pregnancy. American fournal of Obstetrics and Gynecology, 39, 954.

Lock, F. R., Gatling, H. B., and Wells, H. B., (1961). Difficulties in the diagnosis of congenital abnormalities: experience in a study of the effect of rubella on pregnancy. Fournal of the American Medical Association, 178, 711.

Lowrey, G. H., Aster, R. H., Carr, E. A., Ramon, G., Beierwaltes, W. H., and Spafford, N. R. (1958). Early diagnostic criteria of congenital hypothyroidism: comprehensive study of fortynine cretins. American fournal of Diseases of Children, 96, 131.

Man, E. B., Shaver, B. A., Jr., and Cooke, R. E. (1958). Studies of children born to women with thyroid disease. American Fournal of Obstetrics and Gynecology, 75, 728.

Mestman, J. H., Manning, P. R., and Hodgman, J. (1974). Hyperthyroidism and pregnancy. Archives of Internal Medicine, 134, 434.

Mussey, R. D., Plummer, W. A., and Boothby, W. M. (1926). Pregnancy complicating exophthalmic goiter and adenomatous goiter with hyperthyroidism. Fournal of the American Medical Association, 87, 1009.

Nora, J. J., and Nora, A. H. (1974). Can the pill cause birth defects ? New England fournal of Medicine, 291, 731.

Piper, J., and Rosen, J. (1954). Management of hyperthyroidism during pregnancy. Acta Medica Scandinavica, 150, 215.

Shepherd, M., Oppenheim, B., and Mitchell, S. (1971). Childhood Behaviour and Mental Health, University of London Press, London.

Sterling, K., and Brenner, M. A. (1966). Free thyroxine in human serum: simplified measurement with the aid of magnesium precipitation. Fournal of Clinical Investigation, 45, 153.

Stutsman, R. (1931). Mental Measurement of Preschool Children, $A$ Guide to the Merrill-Palmer Scale of Mental Tests. Harcourt, Brace and World. New York.

Tanner, J. M., Whitehouse, R. H., and Goldstein, H. (1972). A Revised System for Estimating Skeletal Maturity from Hand and Wrist Radiographs, with Separate Standards for Carpals and Other Bones, International Children's Centre, Paris.

Warkany, J., and Kalter, H. (1961). Congenital malformations. New England fournal of Medicine, 265, 993.

Wechsler, D. (1949). Manual For The Wechsler Intelligence Scale For Children. Psychological Corporation, New York.

Wechsler, D. (1967). Manual For The Wechsler Preschool and Primary Scale of Intelligence. Psychological Corporation, New York.

Werner, S. C. (1967). Hyperthyroidism in the pregnant woman and the neonate. Fournal of Clinical Endocrinology and Metabolism, 27, 1637.

Correspondence to Prof. D. A. D. Montgomery, The Metabolic Unit, Royal Victoria Hospital, Grosvenor Road, Belfast BT12 6BA. 